\title{
Dry matter and sheep production of four dryland tall fescue-clover pastures 4-6 years after establishment
}

\author{
A.D. BLACK and J.L. MOIR \\ Faculty of Agriculture and Life Sciences, Lincoln University, Lincoln 7647, Canterbury, New Zealand \\ alistair.black@lincoln.ac.nz
}

\begin{abstract}
Effects of tall fescue cultivar ('Advance' and 'Flecha') and clover species (white and subterranean (sub) clovers) combinations on pasture dry matter (DM) and sheep production were assessed in years four (2011/12), five $(2012 / 13)$ and six (2013/14) after establishment in dryland, Canterbury. 'Advance' pastures yielded less total herbage than 'Flecha' pastures (13.9 cf. $16.5 \mathrm{t}$ $\mathrm{DM} / \mathrm{ha}$ ) but more fescue $(8.6 \mathrm{cf} .5 .9 \mathrm{t} \mathrm{DM} / \mathrm{ha})$ and $2.1 \mathrm{t}$ $\mathrm{DM} /$ ha clover in year four, $13.5 \mathrm{t} \mathrm{DM} /$ ha total herbage with more fescue $(8.0 \mathrm{cf} .4 .1 \mathrm{t} \mathrm{DM} / \mathrm{ha}$ ) and $1.9 \mathrm{t} \mathrm{DM} / \mathrm{ha}$ clover in year five, and $11.7 \mathrm{t} \mathrm{DM} /$ ha total herbage, 5.4 $\mathrm{t} \mathrm{DM} /$ ha fescue and $0.8 \mathrm{t} \mathrm{DM} /$ ha clover in year six. Sub clover pastures yielded more total, fescue and clover herbage $(16.9,8.8$ and $3.2 \mathrm{t} \mathrm{DM} / \mathrm{ha})$ than white clover pastures $(13.5,5.7$ and $1.0 \mathrm{t} \mathrm{DM} / \mathrm{ha})$ in year four, more fescue in year five ( $7.2 \mathrm{cf} .4 .9 \mathrm{tDM} / \mathrm{ha})$, and more clover in year six (1.2 cf. $0.3 \mathrm{t} \mathrm{DM} / \mathrm{ha})$. Sheep liveweight gain was greater for sub than white clover pastures in year four (939 cf. $431 \mathrm{~kg} / \mathrm{ha}$ ) and five (697 cf. $481 \mathrm{~kg} / \mathrm{ha}$ ) and $689 \mathrm{~kg} / \mathrm{ha}$ in year six. Therefore, sub clover and 'Advance' were generally more productive than white clover and 'Flecha', but both fescues showed similar persistence after 6 years.
\end{abstract}

Keywords: cultivar, Festuca arundinacea, grass-clover mixtures, liveweight gain, Trifolium subterraneum, Trifolium repens

\section{Introduction}

Many pastoral regions in New Zealand experience periods of summer and autumn moisture stress unless they are irrigated. This reduces the production and persistence of traditional perennial ryegrass (Lolium perenne)-white clover (Trifolium repens) pastures. In these environments inclusion of more drought tolerant grass and clover combinations can enhance pasture production (Mills et al. 2008). 'Advance' tall fescue (Festuca arundinacea) has been shown to persist in some drought prone environments (Black \& Lucas 2000; Milne 2011). There has also been interest in 'Flecha' tall fescue. It was developed from germplasm native to the Mediterranean region and can exhibit less summer activity and more winter growth than cultivars like 'Advance' developed from germplasm native to central and northern Europe (West et al. 2007). 'Flecha' can therefore display some degree of summer dormancy, even during periods of occasional summer rains, as a drought avoidance strategy (Norton et al. 2006). Including subterranean (sub) clover (T. subterraneum) in tall fescue pastures is another strategy to increase pasture production in dry summer environments (Mills et al. 2008). Sub clover, which also originates from the Mediterranean region, can display more winter growth than white clover, and it avoids summer drought by setting seed in the spring before it completes its annual lifecycle (Smetham 2003). Information is needed on the effects of such grass-clover combinations on herbage and livestock production under dryland conditions in New Zealand.

The objective of this study was to assess the effects of tall fescue cultivar ('Advance' and 'Flecha') and clover species (white and sub clovers) combinations on pasture production under sheep grazing in dryland Canterbury. Here, we build on a previous analysis of the first 2 years of data from this experiment (Jusoh 2013) and report the results from years four (2011/12), five (2012/13) and six (2013/14) after establishment. Pasture production was quantified as the accumulation of total herbage dry matter (DM) and its species components, including the incidence of unsown species, and as the liveweight gain and grazing days per hectare of young sheep grazing the four pastures.

\section{Methods \\ Experimental site, preparation and design}

A grazing experiment was conducted at Lincoln University, Canterbury $\left(43^{\circ} 38^{\prime} 55.4^{\prime \prime} \mathrm{S}, 172^{\circ} 27^{\prime} 36.8^{\prime \prime}\right.$ E, $9 \mathrm{~m}$ above sea level) on a flat Templeton silt loam (Cox 1978). The site was previously used for a grazing experiment which compared white clover and Caucasian clover (T. ambiguum) in perennial ryegrass-based pastures (Black et al. 2007). There were four rows (replicates) of plots and each plot was $14 \mathrm{~m} \times 28.5 \mathrm{~m}\left(400 \mathrm{~m}^{2}\right)$, fenced and supplied with stock water. Raceways connected the plots to a small corral. The resident pastures were sprayed with 3 litres/ ha herbicide (540 g/litre glyphosate) in August 2007, then the plots were cultivated and sown with triticale $(\times$ Triticosecale) in September. The triticale was grazed by sheep in December, and then mown to remove residual herbage in January. Plots were then fallowed before 
being ploughed and cultivated in early March 2008 .

The experimental design was a $2^{2}$ factorial of the two cultivars of tall fescue ('Advance' and 'Flecha') and two clover species (white and sub). The four grassclover combinations were assigned randomly to four plots within each of the four replicates.

\section{Pasture establishment}

The pastures were sown on 14 March 2008 using an Øyjoord plot seeder with coulters spaced $0.15 \mathrm{~m}$ apart. The seed mixtures were $20 \mathrm{~kg} / \mathrm{ha}$ 'Advance' or 'Flecha' (both were purported to be infected with $\operatorname{MaxP}{ }^{\circledR}$ endophyte (Epichloë coenophiala syn. Neotyphodium coenophialum)) with either $3 \mathrm{~kg} / \mathrm{ha}$ 'Nomad' white clover and $3 \mathrm{~kg} / \mathrm{ha}$ 'La Lucilla' strawberry clover (T. fragiferum), or $10 \mathrm{~kg} / \mathrm{ha}$ 'Campeda' and $10 \mathrm{~kg} / \mathrm{ha}$ 'Denmark' sub clovers. However, strawberry clover declined over the first 2 years (Jusoh 2013) and was not present in subsequent years. 'Campeda' flowers earlier in spring and generally has larger leaves and longer petioles (leaf stalks) than 'Denmark'.

\section{Sheep}

Hoggets (female, Coopworth, 11-12 months of age) were brought onto the plots in late August or early September and replaced with lambs (female, Coopworth, 6-7 months of age) in March each year from 2011/12 to 2013/14. Sixteen hoggets or lambs were selected as "core" animals to determine liveweight gain; they were blocked on initial liveweight (average was $42.4 \mathrm{~kg}$ for hoggets and $36.9 \mathrm{~kg}$ for lambs) and one animal from each weight block was randomly assigned to each treatment, giving four "core" animals per treatment group. All hoggets were shorn and given an anthelmintic treatment in October, and all lambs received a quarantine anthelmintic before going on to the plots.

\section{Management}

The sheep were rotationally stocked on the four replicates, with each replicate grazed in series (i.e., replicate 1 to 4 ) in each rotation. All groups were shifted to the next replicate on the same day. Stocking rate, duration of grazing and interval between grazing were adjusted for pasture growth rate and mass to maintain similar pasture allowances (approximately $2.5 \mathrm{~kg} \mathrm{DM} /$ sheep/day) for all groups. Stocking rate adjustments were only made on the day the groups were shifted, by adding or removing extra "grazer" sheep. All plots were de-stocked in summer (December or January to March) and winter (June to August) due to slow pasture growth. The means and ranges of number of sheep per group and duration of grazing per plot were 6 (4-12) sheep and 7 (4-9) days for the spring/summer grazing period, and 4 (3-7) sheep and 8 (7-14) days for autumn.
Rotation length was 27 (26-38) days. The total duration of grazing on the experiment was 198 days in 2011/12, 163 days in 2012/13 and 181 days in 2013/14. Each plot was topped once in December post-grazing to remove grass reproductive stem.

The plots had a soil Olsen P of $18 \mathrm{mg} /$ litre, sulphate-S of $5 \mathrm{mg} / \mathrm{kg}$ and $\mathrm{pH}$ of 5.8 when tested in May 2012 and August 2014 (soil samples were taken to $7.5 \mathrm{~cm}$ depth). Each plot received $220 \mathrm{~kg} / \mathrm{ha}$ Sulphur Super 20 (8\% P, $20.6 \%$ S) in August 2012.

\section{Measurements}

Herbage yield was measured using exclusion cages. In May 2011, a random site in each plot was trimmed to $25 \mathrm{~mm}$ height and covered with a $1 \mathrm{~m}^{2}$ cage to prevent grazing. In the following spring (Aug.-Sep.) a $0.2 \mathrm{~m}^{2}$ quadrat sample of the herbage accumulated above $25 \mathrm{~mm}$ was cut and collected, and a subsample was separated into tall fescue, clover and weeds. The clover from the sub clover pastures was separated into sub clover and indigenous (not sown) white clover for all harvests in 2012/13 and 2013/14, and 'Campeda' was separated from 'Denmark' for three harvests in autumn 2014. Indigenous white clover could not be distinguished from the sown 'Nomad' cultivar, and there was no sub clover in the white clover pastures. Samples were dried at $70^{\circ} \mathrm{C}$ for $48 \mathrm{~h}$ and total herbage, tall fescue, clover and weed yields calculated. The process was repeated on different sites for eight more harvests in 2011/12 and seven harvests in 2012/13 and 2013/14. Harvest interval was generally $4-6$ weeks in spring and autumn, 7-14 weeks in summer and 10-14 weeks in winter.

Liveweight gain per hectare was estimated as the change in average liveweight of the "core" animals multiplied by stocking rate. The "core" animals were weighed unfasted when they were first put onto the plots and at the end of each grazing rotation. Grazing days, which is a measure of stock carrying capacity of pastures, were calculated as stocking rate (sheep/ha) multiplied by duration of grazing (days) for each plot.

The nutritive value of the herbage offered to the sheep was estimated by collecting a representative sample (cut to $25-30 \mathrm{~mm}$ above ground) from each plot immediately before grazing. Samples were dried at $70^{\circ} \mathrm{C}$ for $48 \mathrm{~h}$, ground and analysed for metabolisable energy and crude protein contents by near infrared reflectance spectroscopy.

\section{Data analysis}

Dry matter yields of total herbage, tall fescue, clover and weeds were summed over harvests within each year and then analysed for each harvest date. Liveweight gain and grazing days per hectare were also summed within each year before analysis. Significant $(\alpha=0.05)$ effects 
of tall fescue and clover treatments and their interaction were tested by analysis of variance in Genstat 16 software. For liveweight gain and grazing days, each treatment group of animals was not replicated so the two-way interaction was used as experimental error to give two replicate groups for the tall fescue and clover main effects.

\section{Rainfall and temperature}

The long-term mean (LTM; 1975-2002) rainfall is 624 $\mathrm{mm} /$ year (July to June) and ranges from 41-64 mm/ month throughout the year (Table 1). Rainfall was lower than normal in 2011/12 (582 mm) and higher than normal in 2012/13 (795 mm) and 2013/14 (712 $\mathrm{mm}$ ). Monthly rainfall was variable and ranged from 9 $\mathrm{mm}$ in May 2012 to $205 \mathrm{~mm}$ in June 2013. The LTM daily air temperature at this site is $11.5^{\circ} \mathrm{C}$ for the year and increases from $6.1^{\circ} \mathrm{C}$ in July to $16.5^{\circ} \mathrm{C}$ in January.

\section{Results and Discussion}

Total herbage yield was greater $(\mathrm{P}<0.05)$ for 'Flecha' than 'Advance' pastures and for sub clover than white clover pastures for all harvests in 2011/12 (Figure 1a). There were tall fescue by clover treatment interactions $(\mathrm{P}<0.05)$ in that year, indicating the sub clover benefit was greater for 'Advance' than 'Flecha' pastures from February to May. In 2012/13, total yield was greater $(\mathrm{P}<0.05)$ for 'Flecha' than 'Advance' pastures in September and October, and greater $(\mathrm{P}<0.05)$ for sub than white clover pastures in November. There were no differences for total yield by the end of 2012/13

Table 1 Mean monthly and annual rainfall $(\mathrm{mm})$ from Broadfields meteorological station located $2 \mathrm{~km}$ north of the experimental site at Lincoln University, Canterbury. Long-term means (LTM) are for 1975-2002.

\begin{tabular}{lrrrr}
\hline & \multicolumn{3}{c}{ Year } & LTM \\
\cline { 2 - 4 } & $\mathbf{2 0 1 1 / 1 2}$ & $\mathbf{2 0 1 2 / 1 3}$ & $\mathbf{2 0 1 3 / 1 4}$ & \\
\hline Jul. & 21 & 41 & 28 & 64 \\
Aug. & 75 & 105 & 36 & 62 \\
Sep. & 29 & 26 & 31 & 43 \\
Oct. & 103 & 65 & 69 & 51 \\
Nov. & 53 & 65 & 46 & 52 \\
Dec. & 57 & 33 & 64 & 50 \\
Jan. & 28 & 30 & 11 & 51 \\
Feb. & 40 & 22 & 54 & 41 \\
Mar. & 66 & 38 & 122 & 50 \\
Apr. & 23 & 58 & 161 & 46 \\
May & 9 & 107 & 46 & 50 \\
Jun. & 79 & 205 & 43 & 64 \\
Annual & 582 & 795 & 712 & 624 \\
\hline
\end{tabular}

and in the final year. However, botanical composition differed significantly between the four grass-clover combinations in each year.

All four pastures contained significant amounts of weeds (Figure 1b), which can influence the interpretation of total yield results. The weeds species were mainly hair grass (Vulpia sp.), soft brome (Bromus hordeaceus), hawksbeard (Crepis capillaris) and dandelion (Taraxacum officinale). In 2011/12 and 2012/13, weed yield was lower $(\mathrm{P}<0.05)$ for 'Advance' than 'Flecha' pastures for all harvests, and lower $(\mathrm{P}<0.05)$ for sub than white clover pastures from November to May. This suggests that the 'Advance' and sub clover pastures were better at suppressing weeds than the 'Flecha' and white clover pastures. In 2013/14, weed content remained lower $(\mathrm{P}<0.05)$ for sub than white clover pastures, but was similar for both fescues, which was possibly due to a decrease in the contribution of 'Advance' tall fescue to total yield. Therefore, the tall fescue and clover yields were also analysed.

In $2011 / 12$, tall fescue yield was greater $(\mathrm{P}<0.05)$ for 'Advance' than 'Flecha' from February to May, and for sub than white clover pastures for most harvests (Figure 1c). It was also greater $(\mathrm{P}<0.05)$ for 'Advance' than 'Flecha' and sub than white clover pastures from November to May in 2012/13. However, in the final year, the yield of 'Advance' decreased to the extent that it was now similar to the yield of 'Flecha', and sub clover only improved the yield of tall fescue for one harvest in October. Over the first 2 years, Jusoh (2013) reported that 'Advance' and 'Flecha' produced similar yields by May 2008 (0.5 t DM/ha), but 'Advance' yielded more in 2008/09 (5.9 cf. 4.7 t DM/ha) and 2009/10 (5.9 cf. 5.1 t DM/ha). Therefore, 'Advance' was more productive over the first 5 years, but both cultivars showed similar persistence after 6 years. Under partial irrigation in Canterbury, Minneé et al. (2010) found that 'Advance' and 'Resolute' (another "Mediterranean" tall fescue) produced similar yields in the first 2 years, but that 'Resolute' had failed by the third year producing 3.8 t DM/ha less than 'Advance'. Further work is required to clarify differences in persistence between 'Advance' and 'Flecha' tall fescues.

Total clover yield was similar for both tall fescues and greater $(\mathrm{P}<0.05)$ for sub than white clover pastures for all harvests in 2011/12 (Figure 1d). Any differences in clover yield in 2012/13 were not significant. In $2013 / 14$, clover yield was greater $(P<0.05)$ for sub than white clover pastures from November to May, and similar for both fescues. The reasons for the decline in clover yields in the final year were unclear, but may have contributed to the lower tall fescue yields in that year. However, the sub clover benefit was consistent with the results from the first 2 years (Jusoh 2013). 
(a)

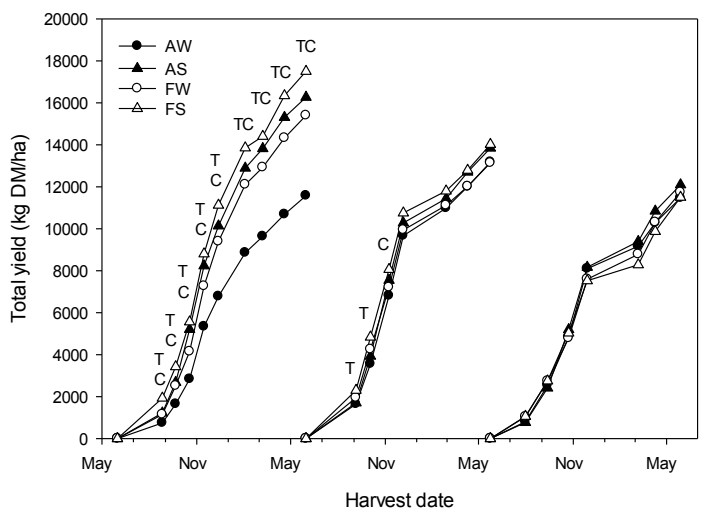

(b)

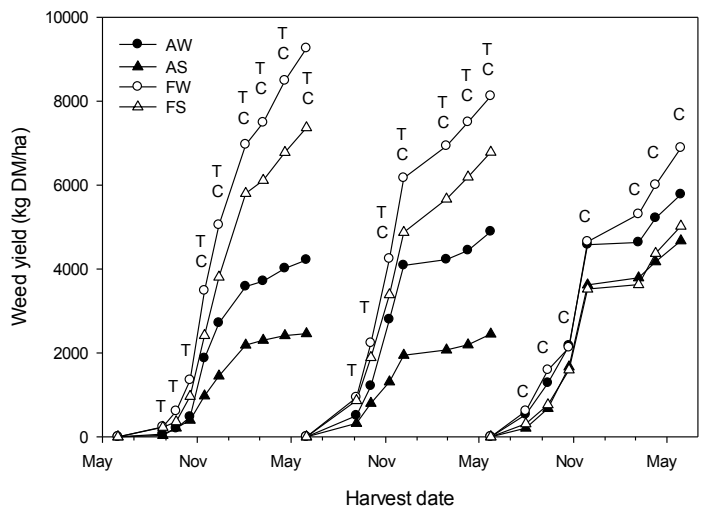

(c)

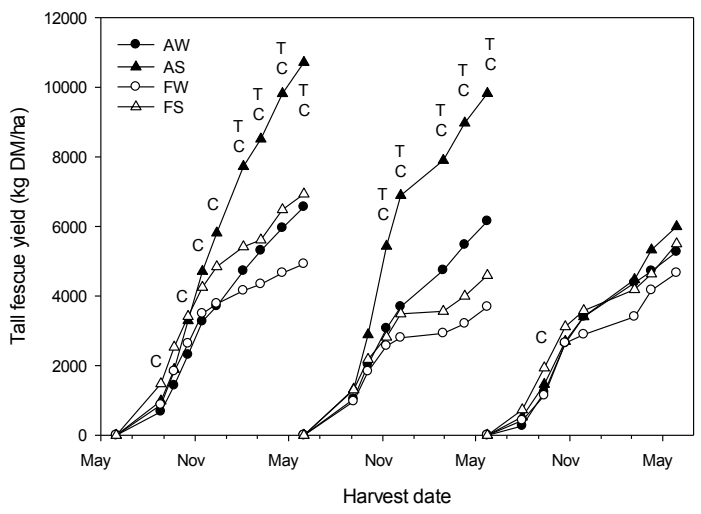

(d)



Figure 1 Accumulated yields of total (a), weed (b), tall fescue (c) and clover (d) herbage dry matter (DM) for pastures of 'Advance' (A) or 'Flecha' $(F)$ tall fescue with white (W) or subterranean (S) clover in years four (2011/12), five (2012/13) and six (2013/14) after establishment in dryland, Canterbury. Significant $(\alpha=0.05)$ tall fescue and clover effects and their interaction are indicated for each harvest as T, C and TC, respectively.

It was also in agreement with an adjacent experiment where dryland cocksfoot (Dactylis glomerata)-sub clover pastures were more productive than cocksfootwhite clover pastures over 9 years (Mills et al. in press).

The serial yield measurements indicated that the winter growth of 'Flecha' tall fescue was similar to that of 'Advance' (Figure 1c). Other studies have suggested that 'Flecha' can exhibit more winter growth than "Continental" types of tall fescue such as 'Advance' (West et al. 2007). However, the winter conditions at Lincoln may not have been mild enough for any growth advantage by 'Flecha', and weed competition may have influenced the growth of all sown species. 'Flecha' did show less summer activity than 'Advance' in years four and five (Figure 1c), suggesting some level of summer dormancy (Norton et al. 2006), even when there were periods of rains (Table 1). However, this would have reduced its suppression power against weeds. In contrast, sub clover exhibited more spring growth than white clover, particularly in years four and six (Figure 1d).
Separating out the different clover species and cultivars in the sub clover pastures revealed that sub clover provided $61 \%$ and $76 \%$ of the total clover yield in 2012/13 and 2013/14, respectively. The rest was indigenous white clover. 'Denmark' dominated 'Campeda' when separated in autumn 2014, with 'Denmark' providing over $90 \%$ of total sub clover yield. Therefore, the prostrate, later flowering 'Denmark' sub clover appeared to be better suited than 'Campeda' to the climatic and grazing conditions at this site. Further work is needed to confirm this result.

There were no significant effects of tall fescue cultivar on annual sheep liveweight gains and grazing days (Table 2). Liveweight gain was significantly greater $(\mathrm{P}<0.05)$ for sub clover than white clover pastures in $2012 / 13$, and there were more $(\mathrm{P}<0.05)$ grazing days on the sub clover than white clover pastures in 2011/12 and 2012/13. The nutritive value of the herbage on offer to the sheep was similar for all pastures, although metabolisable energy and crude 
protein contents were higher $(\mathrm{P}<0.05)$ for sub than white clover pastures in 2011/12 (Table 3). Therefore, greater liveweight gain from the sub clover pastures was associated with more grazing days, increased nutritive value and more total clover compared with the white clover pastures. These effects are consistent with sheep production results for dryland cocksfootsub clover pastures (Mills et al. 2015). Any yield differences between the 'Advance' and 'Flecha' pastures did not result in meaningful differences for liveweight gain.

\section{Conclusions}

Under dryland conditions, 'Flecha' tall fescue pastures produced greater yields of total herbage than 'Advance' tall fescue pastures in year four after establishment and similar total yields in years five and six. However, 'Advance' pastures yielded more fescue and less weeds than 'Flecha' pastures in years four and five, and both cultivars showed similar persistence after 6 years.

The inclusion of sub clover in the tall fescue pastures increased total clover yield compared to white clover, which led to a significant increase in sheep liveweight gain in one of the three years. 'Denmark' dominated
'Campeda' in the sub clover pastures, indicating that 'Denmark' was better suited to the climatic and grazing conditions.

\section{ACKNOWLEDGEMENTS}

We thank Agricom for funding the experiment from 2011 to 2014, Sonia Patelli and Dan Dash for technical assistance, and B.Agr.Sc. Honours students Stephen Dellow, Brian Maw, Ben Peter and Louise Livesey.

\section{REFERENCES}

Black, A.D.; Lucas, R.J. 2000. Caucasian clover was more productive than white clover in grass mixtures under drought conditions. Proceedings of the New Zealand Grassland Association 62: 183-188.

Black, A.D.; Lucas, R.J.; Moot, D.J.; Sedcole, J.R. 2007. Liveweight gains of lambs from Caucasian clover/ryegrass and white clover/ryegrass swards on soils of high and low fertility. Grass and Forage Science 62: 225-238.

Cox, J.E. 1978. Soils and agriculture of part Paparua County, Canterbury, New Zealand. New Zealand Soil Bureau Bulletin No. 34. New Zealand Department of Scientific and Industrial Research, Wellington. 128 pp.

Table 2 Sheep liveweight gain and grazing days per hectare for tall fescue-clover pastures in response to tall fescue cultivar ('Advance' and 'Flecha') and clover species (white and subterranean) in years four (2011/12), five (2012/13) and six (2013/14) after establishment in dryland, Canterbury.

\begin{tabular}{|c|c|c|c|c|c|c|}
\hline \multirow[t]{2}{*}{ Treatment } & \multicolumn{3}{|c|}{ Liveweight gain (kg/ha) } & \multicolumn{3}{|c|}{ Grazing days/ha } \\
\hline & $2011 / 12$ & $2012 / 13$ & $2013 / 14$ & $2011 / 12$ & $2012 / 13$ & 2013/14 \\
\hline 'Advance' & 619 & 562 & 594 & 6350 & 4241 & 6569 \\
\hline 'Flecha' & 751 & 615 & 785 & 6825 & 4291 & 6947 \\
\hline$P$ value & 0.755 & 0.762 & 0.482 & 0.719 & 0.942 & 0.275 \\
\hline White & 431 & 481 & 639 & 5784 & 3838 & 6588 \\
\hline Sub. & 939 & 697 & 739 & 7391 & 4694 & 6928 \\
\hline$P$ value & 0.059 & 0.035 & 0.728 & 0.049 & 0.007 & 0.347 \\
\hline
\end{tabular}

Table 3 Average metabolisable energy (ME) and crude protein (CP) contents of pre-grazing herbage for pastures of 'Advance' (A) or 'Flecha' (F) tall fescue with white (W) or subterranean (S) clover in years four (2011/12), five (2012/13) and six $(2013 / 14)$ after establishment in dryland, Canterbury.

\begin{tabular}{|c|c|c|c|c|c|c|}
\hline \multirow[t]{2}{*}{ Treatment } & \multicolumn{3}{|c|}{ ME (MJ/kg DM) } & \multicolumn{3}{|c|}{ CP (\%) } \\
\hline & $2011 / 12$ & $2012 / 13$ & $2013 / 14$ & $2011 / 12$ & $2012 / 13$ & $2013 / 14$ \\
\hline AW & 9.3 & 9.5 & 10.5 & 12.4 & 13.5 & 17.5 \\
\hline AS & 10.0 & 9.8 & 10.5 & 15.9 & 13.4 & 18.2 \\
\hline FW & 9.3 & 9.2 & 10.6 & 12.6 & 12.5 & 17.9 \\
\hline FS & 9.8 & 9.2 & 10.6 & 16.3 & 12.9 & 18.1 \\
\hline $\mathrm{P}$ value $(\mathrm{T})$ & NS & NS & NS & NS & NS & NS \\
\hline$P$ value $(C)$ & $<0.05$ & NS & NS & $<0.001$ & NS & NS \\
\hline
\end{tabular}

$\mathrm{T}=$ tall fescue effect, $\mathrm{C}=$ clover effect, NS = not significant 
Jusoh, S. 2013. Grazing management and pasture production of tall fescue-legume mixtures in dryland pastures. PhD thesis. Lincoln University.

Mills, A.; Lucas, R.J.; Moot, D.J. 2015. 'MaxClover' grazing experiment II: sheep liveweight production from six grazed dryland pastures over 8 years. New Zealand Journal of Agricultural Research 58: 5777.

Mills, A.; Lucas, R.J.; Moot, D.J. in press. 'MaxClover' grazing experiment: I. Annual yields, botanical composition and growth rates of six dryland pastures over nine years. Grass and Forage Science: doi:10.1111/gfs.12132.

Mills, A.; Smith, M.C.; Lucas, R.J.; Moot, D.J. 2008. Dryland pasture yields and botanical composition over 5 years under sheep grazing in Canterbury. Proceedings of the New Zealand Grassland Association 70: 37-44.

Milne, G.D. 2011. Can pasture persistence be improved through the use of non-ryegrass species? Pasture persistence symposium. Grassland Research and Practice Series 15: 157-162.
Minneé, E.M.K.; Knight, T.L.; Sutherland, B.L.; Vlambing, J.B.; Fletcher, L.R.; Clark, D.A. 2010. Herbage production from perennial ryegrass and tall fescue pastures under irrigation in the Canterbury and Waikato regions of New Zealand. Proceedings of the New Zealand Grassland Association 72: 185-190.

Norton, M.R.; Volaire, F.; Lelievre, F. 2006. Summer dormancy in Festuca arundinacea Schreb., the influence of season of sowing and a simulated midsummer storm on two contrasting cultivars. Australian Journal of Agricultural Research 57: 1267-1277.

Smetham, M.L. 2003. Subterranean clover (Trifolium subterraneum): its history and current and future research in New Zealand. Legumes for Dryland Pastures. Grassland Research and Practice Series 11: 61-72.

West, C.P.; Volaire, F.; Lelievre, F. 2007. Tiller survival after drought of 'Grasslands Flecha' tall fescue as influenced by endophyte. Proceedings of the 6th International Symposium on Fungal Endophytes of Grasses. Grassland and Research Practice Series 13: 267-269. 